\title{
PENGARUH KESELAMATAN DAN KESEHATAN KERJA TERHADAP KEPUASAN KERJA
}

(Studi pada Karyawan Bagian Pabrikasi PG Kebon Agung Malang)

\author{
Skolastika Dian Rosita Sari, Eko Agus Susilo, Harril Brimantyo \\ Fakultas Ilmu Sosial dan Ilmu Politik Universitas Merdeka Malang \\ Email:franz.dian@yahoo.co.id
}

\begin{abstract}
This study aims to determine the impact of and health on job satisfaction in Sugar Refinery Kebon Agung Malang. The number of population is 241 employees. The sampling technique using simple random sampling. Sample in this study using the Slovin formula, obtained the results as many as 150 respondents. This study using descriptive analysis with quantitative approach using a questionnaire as a data collection tool and using the technique of multiple linear regression analysis to measure the influence of independent variables on the dependent variable is the salvation (X1) and health (X2) as the independent variable and job satisfaction as $a$ variable dependent $(Y)$. The results of this research stated that safety and health has positive and significant impact to the job satisfaction in Sugar Refinery Kebon Agung Malang. This is shown by the value of Adjusted $R$ Square of 0.427 or $4.27 \%$ by $F$ significance 0,000 $F$ and partial effect also show significant impact, this study found that health variables has a greater impact influence on other vaiables, this is the show with a regression coeficient of 0.636.
\end{abstract}

\section{Keywords: Safety and Work Health, Job Satisfaction}

Abstrak : Penelitian ini bertujuan untuk mengetahui seberapa besar pengaruh Keselamatan dan Kesehatan Kerja terhadap Kepuasan Kerja PG Kebon Agung Malang. Jumlah anggota populasi pada penelitian ini sebanyak 241 orang karyawan. Teknik pengambilan sampel menggunakan simple random sampling. Sampel dalam penelitian ini menggunakan rumus Slovin, diperoleh hasil sebanyak 150 responden. Penelitian ini menggunakan analisis deskriptif dengan pendekatan kuantitatif yang menggunakan kuesioner sebagai alat pengumpulan data dan menggunakan teknik analisis regresi linear berganda untuk mengukur pengaruh dari variabel bebas terhadap variabel terikat yaitu keselamatan (X1) dan kesehatan kerja (X2) sebagai variabel independent dan kepuasan kerja sebagai variabel dependent (Y). Hasil dari penelitian ini menyatakan bahwa keselamatan dan kesehatan kerja berpengaruh signifikan dan positif terhadap kepuasan kerja PG Kebon Agung Malang. Hal ini ditunjukkan dengan nilai Adjusted R Square sebesar 0,427 atau $4,27 \%$ dengan signifikansi $F$ sebesar 0,000 dan pengaruh secara parsial juga menunjukkan signifikan, dalam penelitian ini ditemukan bahwa variabel Kesehatan Kerja mempunyai pengaruh yang lebih besar terhadap variabel lainnya, hal ini ditunjukkan dengan Koefisien Regresi sebesar 0,636 .

\section{Kata Kunci: Keselamatan dan Kesehatan Kerja, Kepuasan Kerja}


Indonesia dan negara-negara di wilayah Asia Tenggara akan membentuk sebuah kawasan yang terintegrasi yang dikenal sebagai Masyarakat Ekonomi Asean (MEA). MEA merupakan bentuk realisasi dari tujuan akhir integrasi ekonomi di kawasan Asia Tenggara. Bagi Indonesia sendiri, MEA akan menjadi kesempatan yang baik karena hambatan perdagangan akan cenderung berkurang bahkan menjadi tidak ada. Hal tersebut akan berdampak pada peningkatan ekspor yang pada akhirnya akan meningkatkan Gross Domestic Product Indonesia. Di sisi lain, muncul tantangan baru bagi Indonesia berupa permasalahan homogenitas komoditas yang diperjualbelikan, contohnya untuk komoditas pertanian, karet, produk kayu, tekstil, dan barang elektronik (Santoso, 2008). Dalam hal ini competition risk akan muncul dengan banyaknya barang impor yang akan mengalir dalam jumlah banyak ke Indonesia yang akan mengancam industri lokal dalam bersaing dengan produk-produk luar negri yang jauh lebih berkualitas. Hal ini pada akhirnya akan meningkatkan defisit neraca perdagangan bagi Negara Indonesia sendiri.

Keselamatan dan kesehatan kerja (K3) adalah modal utama untuk para sumber daya manusia yang bekerja pada perusahaan terutama pada bagian produksi. Jika K3 tidak diberikan secara baik akan merugikan karyawan tersebut dan bisa juga berdampak buruk pada perusahaan. Keselamatan kerja menurut Mondy (2008) adalah perlindungan karyawan dari cidera yang disebabkan oleh kecelakaan yang berkaitan dengan pekerjaan. Sedangkan Kesehatan kerja menurut Mathis dan Jakson (2002) adalah kondisi yang merujuk pada kondisi fisik, mental dan stabilitas emosi secara umum. Kepuasan kerja adalah keadaan emosional yang menyenangkan atau tidak menyenangkan dengan mana para karyawan memandang pekerjaan (Handoko, 2008). Kepuasan dapat terbentuk salah satunya terkait dengan jaminan keselamatan dan kesehatan kerja.

PT Kebon Agung mempunyai dua pabrik yaitu PG Kebon Agung yang berada di kota Malang dan PG Trangkil yang berada di kota Surabaya, bergerak dalam industri gula yaitu penghasil gula kristal. Mesin-mesin yang digunakan pabrik gula Kebon Agung juga sangat modern dan berbahaya dengan setiap hari memproduksi gula. Jika para karyawan pabrik tidak hati-hati akan beresiko kecelakaan.
Resiko kecelakaan kerja ini sering terjadi pada stasiun pemurnian nira dan stasiun penguapan. Pada stasiun yang menjadi tempat pengolahan nira, yaitu stasiun pemurnian dan stasiun penguapan, stasiun ini merupakan tempat yang memiliki kecelakaan kerja tertinggi, yang di mana nira tersebut diolah dengan menggunakan mesin yang bersuhu tinggi untuk menghasilkan nira kental dan uap air, dan pada stasiun penguapan, uap nira tersebut di keluarkan melalui tabung-tabung yang terdapat pada ujung ketel. Pada proses pengolahan nira dan proses penguapan inilah resiko kecelakaan kerja karyawan menjadi tinggi.

\section{KAJIAN PUSTAKA \\ Sumber Daya Manusia}

Menurut Hasibuan (2003) sumber daya manusia adalah kemampuan terpadu dari daya pikir dan daya fisik yang dimiliki individu. Pelaku dan sifatnya dilakukan oleh keturunan dan lingkungannya, sedangkan prestasi kerjanya dimotivasi oleh keinginan untuk memenuhi kepuasannya.

\section{Keselamatan Kerja}

Keselamatan kerja menurut Mondy (2008) adalah perlindungan karyawan dari cidera yang disebabkan oleh kecelakaan yang berkaitan dengan pekerjaan. Keselamatan kerja berkaitan juga dengan mesin, pesawat, alat kerja, bahan dan proses pengolahan, landasan kerja dan lingkungan kerja serta cara-cara melakukan pekerjaan dan proses produksi.

\section{Indikator Keselamatan Kerja}

a. Tempat Kerja

Tempat kerja merupakan lokasi dimana para karyawan melaksanakan aktifitas kerjanya.

b. Mesin dan Peralatan

Mesin dan peralatan adalah bahian dari kegiatan operasional dalam proses produksi yang biasanya berupa alat-alat berat dan ringan.

c. Jaminan Keselamatan

Jaminan keselamatan yaitu berupa alat-alat yang menjamin keselamatan kerja di lingkungan perusahaan.

\section{Kesehatan Kerja}

Menurut Mathis dan jackson (2002), kesehatan kerja adalah kondisi yang merujuk pada kondisi fisik, mental dan stabilitas emosi secara umum. Individu yang sehat adalah 
individu yang bebas dari penyakit, cidera serta masalah mental emosi yang bisa mengganggu aktivitas.

\section{Indikator Kesehatan Kerja}

a. Keadaan dan Kondis Karyawan

Kedaan dan kondis karyawan adalah keadaan yang dialami oleh karyawan pada saat bekerja yang mendukung aktivitas dalam bekerja.

b. Lingkungan Kerja

Lingkungan kerja adalah lingkungan yang lebih luasdari tempat kerja yang mendukung aktifitas karyawan dalam bekerja.

c. Perlindungan Karyawan

Perlindungan karaywan merupakan fasilitas yang diberikan untuk menunjang kesejahteraan karyawan.

\section{Kepuasan Kerja}

Menurut Siagian (2002) kepuasan kerja merupakan suatu cara pandang seseorang baik yang bersifat positif maupun yang bersifat negatif tentang pekerjaannya. Oleh karena itu, tidak sederhana dalam melakukan analisis terhadap kepuasan kerja karyawan, banyak faktor yang perlu mendapat perhatian dalam menganalisis kepuasan kerja seseorang.

\section{Indikator Kepuasan Kerja}

\section{Turnover}

Kepuasan kerja lebih tinggi dihubungkan dengan turnover karyawan yang rendah. Sedangkan karyawan-karyawan yang kurang puas biasanya turnovernya lebih tinggi.

2. Tingkat ketidakhadiran (absen) kerja

Karyawan-karyawan yang kurang puas cenderung tingkat ketidakhadiran (absen) tinggi. Mereka sering tidak hadir kerja dengan alasan yang tidak logis dan subjektif.

3. Tingkat Pekerjaan

Karyawan-karyawan yang menduduki tingkat pekerjaan yang lebih tinggi cenderung lebih puas daripada karyawan yang menduduki tingkat pekerjaan yang lebih rendah. Karyawan-karyawan yang tingkat pekerjaannya lebih tinggi menunjukkan kemampuan kerja yang baik dan aktif dalam mengemukakan ide-ide serta kreatif dalam bekerja.

\section{Hipotesis}

H1 : Keselamatan kerja berpengaruh terhadap kepuasan kerja

H2 : Kesehatan kerja berpengaruh terhadap kepuasan kerja

H3 :Kesehatan dan Kesehatan kerja berpengaruh terhadap kepuasan kerja

\section{Variabel Bebas $(\mathbf{X})$}

Variabel bebas (independent variable) sering disebut sebagai variabel stimulus (rangsangan). Variabel ini yang mempengaruhi variabel-variabel yang lain. Variabel bebas yang digunakan dalam penelitian ini adalah keselamatan kerja $\left(\mathrm{X}_{1}\right)$ dan kesehatan kerja $\left(\mathrm{X}_{2}\right)$.

\section{Variabel Terikat (Y)}

Variabel bebas (dependent variable) sering disebut sebagai variabel output (keluaran). Variabel ini merupakan variabel yang dipengaruhi atau yang menjadi sebab akibat karena adanya variabel bebas karena adanya variabel bebas. Variabel terikat yang digunakan dalam penelitian ini adalah kepuasan kerja (Y).

\section{Definisi Operasional Variabel}

Definisi operasional variabel adalah aspek penelitian yang memberikan informasi kepada kita tentang bagaimana cara untuk mengukur variabel.

1. Keselamatan Kerja $\left(\mathrm{X}_{1}\right)$

Indikator-indikator yang membentuk keselamatan kerja dalam penelitian ini adalah :

a. Tempat Kerja

Tempat kerja merupakan lokasi dimana para karyawan melaksanakan aktifitas kerjanya.

b. Mesin dan Peralatan

Mesin dan peralatan adalah bagian dari kegiatan operasional dalam proses produksi yang biasanya berupa alat-alat berat dan ringan.

c. Jaminan Keselamatan

Jaminan keselamatan yaitu berupa alatalat yang menjamin keselamatan kerja di lingkungan perusahaan.

\section{METODE}

\section{Populasi dan Sampel}

Populasi penelitian di PG Kebon Agung Malang berjumlah 241 orang. Pada penelitian ini peneliti dapat mengetahui hasil pengambilan sampel dengan menggunakan rumus slovin. 
Penentuan ukuran sampel penelitian, Slovin memasukkan unsur kelonggaran ketidaktelitian karena kesalahan pengambilan sampel yang masih dapat ditoleransi. Nilai toleransi ini dinyatakan dalam presentase, misalnya $5 \%$.

$$
\begin{aligned}
& \mathrm{n}=\frac{\mathrm{N}}{1+\mathrm{N} e^{2}} \\
& \mathrm{n}=\frac{241}{1+241(0,05)^{2}} \\
& \mathrm{n}=\frac{241}{1+0,6025} \\
& \mathrm{n}=\frac{241}{1,6025} \\
& \mathrm{n}=150,39=150
\end{aligned}
$$

Maka jumlah sampel yang diambil dalam penelitian ini berjumlah 150 responden.

\section{Teknik Pengumpulan Data}
a. Wawancara
b. Kuisioner
c. Kepustakaan
d. Observasi

\section{Lokasi Penelitian}

Lokasi dalam penelitian ini bertempat di PG Kebon Agung Malang Jalan Raya Kebon Agung 1 Kec. Pakisaji Kab. Malang 651052. Peneliti memilih lokasi penelitian di PG Kebon Agung Malang karena pabrik gula yang berada di Malang dan usia pabrik yang sudah tua adalah PG Kebon Agung Malang sehingga banyak cerita perjalanan tentang PG Kebon Agung Malang. Selain itu peneliti juga ingin mengetahui dan menganalisis seberapa besar pengaruh keselamatan dan kesehatan kerja terhadap kepuasan kerja di PG Kebon Agung Malang.

\section{HASIL DAN PEMBAHASAN}

\section{Gambaran Umum PG Kebon Agung Malang}

Pabrik Gula Kebon Agung didirikan oleh seseorang pengusaha Tiongkok Tuan Tan Tjwanbie pada tahun 1905. PG kebonagung memulai aktifitasnya tahun 1908 dengan produksi 8000 pikuls tebu atau setara dengan 5000 kuintal tebu perharinya. Tahun 1913 kapasitas produksi pabrik dinaikkan menjadi 10000 pikuls tebu perharinya. Dalam data tersebut juga dituliskan bahwa selama kepemilikan Tan Tjwan Bie telah terjadi pergantian Administrateur dari Kwee Lian Tik ke Tan Boen Tjiang.Pada tahun 1917 pengelolaan PG kebon agung diserahkan kepada Naamloze Vennotschap (NV) \&
Lanbow Maatschapij Tiedeman \& van Kerchem (TvK) yang sekaligus menjadi direksinya. Pada tanggal 20 Maret 1918 bentuk usaha yang semula perorangan dirubah menjadi usaha perseroan dengan nama NV Suikerfabriek Keboen Agoeng dan Tan Tjwan Bie sebagai direkturnya.Pada tahun 1932 seluruh saham NV S.F Kebon Agung tergadaikan kepada De Javasche Bank. Tahun 1937 kapasitas giling dinaikkan menjadi 1800 tth. Pada tahun 1976-1978 diadakan Rehabilitasi, Perluasan dan Modernisasi (RPM) sehingga kapasitas gilingan menjadi 2500 th. Dari program ini telah dilakukan antara lain penambahan kapasitas produksi gula, perbaikan dan penggantian mesin-mesin yang sudah dimakan usia sebanyak 70-80\%, dan tahun 1977 merupakan Renovasi tahap II yang telah dicanangkan pada RPM ini. Pada tanggal 25 Februari 1992, Bank Indonesia mendirikan Yayasan Kesejahteraan Karyawan Bank Indonesia (YKK-BI) dan memutuskan yayasan inilah yang menjadi pemegang saham tunggal PG Kebon Agung. Tahun 1998-2001 dilakukan Program Penyehatan sehingga kapasitas giling menjadi 4700 tth. Dari tahun 2001 hingga 2004 dilakukan perbaikan dan penggantian mesin untuk mengangkat kemantapan kinerja dan efisiensi pabrik dengan sasaran kapasitas giling 5000 th. Sejak tahun 2005 PG Kebon Agung melakukan program pengembangan PG Kebon Agung dengan sasaran kapasitas giling 10.000 ton tebu upgradiable 15.000 tth.

\section{Penyajian Instrumen Penelitian}

Kuesioner yang dimuat dalam penelitian ini untuk disebarkan kepada responden sebanyak 150 orang. Dari penelitian yang dilakukan terdiri dari 18 pertanyaan dari semua variabel yang ada, maka dilakukan uji validitas dengan tujuan untuk mengetahui signifikansi data yang diperoleh dari hasil jawaban responden yang ada, dengan bantuan komputer program SPSS (Statistical Product and Service Solutions) versi 16 for windows.

\section{Uji Validitas}

Validitas diukur dengan membandingkan nilai korelasi masing-masing indikator dengan nilai korelasi tabel ( $\mathrm{r}$ tabel). Nilai $\mathrm{r}$ tabel sebesar 0,159 . Pengolahan data terlihat dari 18 item yang diuji, semua item memiliki nilai koefisien korelasi positif dan lebih besar dari $r$ tabel, serta probabilitasnya lebih kecil dari $\alpha=$ $10 \%$, artinya ada hubungan yang signifikan 
antara skor masing-masing item dengan skor total. Kolerasi yang signifikan menunjukkan bahwa item memang benar-benar dapat digunakan untuk mengukur variabel yang akan diukur, dengan kata lain instrumen yang digunakan valid dengan demikian dapat dipakai dalam penelitan.

\section{Reliabilitas}

\section{Tabel 1 Hasil Uji Reliabilitas}

\begin{tabular}{|c|c|c|c|}
\hline Variabel & $\begin{array}{c}\text { Cronbach's } \\
\text { Alpha }\end{array}$ & $\begin{array}{c}\text { Standart } \\
\text { Reliabilitas }\end{array}$ & Keterangan \\
\hline $\begin{array}{c}\text { Keselamatan } \\
\text { Kerja } \\
(\mathrm{X} 1)\end{array}$ & 0,589 & 0,06 & Reliabel \\
\hline $\begin{array}{c}\text { Kesehatan } \\
\text { Kerja }\end{array}$ & 0,689 & 0,06 & Reliabel \\
\hline $\begin{array}{c}\text { Kepuasan } \\
\text { Kerja } \\
(\mathrm{Y})\end{array}$ & 0,716 & 0,06 & Reliabel \\
\hline
\end{tabular}

Sumber : Data Primer Diolah, 2016

Instrumen dinyatakan tidak reliabel jika nilai reliabilitas yang diperoleh mencapai 0,06 (Nurgiyanto, 2000). Hasil uji reliabilitas yang disajikan pada tabel di atas menunjukkan bahwa masing-masing nilai koefisien reliabilitas lebih besar dari 0,06 sehingga instrumen yang digunakan dinyatakan reliabel.

\section{Analisis Regresi Berganda}

Penelitian ini menggunakan analisisn regresi linier berganda. Analisis linier berganda digunakan untuk membuktikan ada tidaknya pengaruh yang signifikan antara variabel (X1) keselamatan kerja, (X2) kesehatan kerja dan (Y) kepuasan kerja pada PG Kebon Agung Malang. Pengujian analisis digunakan untuk mengetahui hubungan antar variabel secara simultan dan parsial. Perhitungan analisis regresi linier berganda ini menggunakan program SPSS 16.0 for windows. Berikut ini merupakan hasil uji analisis regresi linier berganda.
Tabel 2. Hasil Uji Analisis Regresi Linier Berganda

\begin{tabular}{|c|c|c|c|c|}
\hline Variabel & $\begin{array}{c}\text { Koefisin } \\
\text { Regresi (B) }\end{array}$ & $t$ hitung & Sig. & Keterangan \\
\hline Constant & 2,513 & & & \\
\hline $\begin{array}{l}\text { Keselamatan } \\
\text { Kerja }\end{array}$ & 0,238 & 2,840 & 0,005 & Signifikan \\
\hline $\begin{array}{l}\text { Kesehatan } \\
\text { Kerja }\end{array}$ & 0,636 & 8,689 & 0,000 & Signifikan \\
\hline $\begin{array}{l}\text { R } \\
\text { R Square } \\
\text { Adjusted R } \\
\text { Square } \\
\text { F hitung } \\
\text { F tabel } \\
\text { Sig. F } \\
\text { A }\end{array}$ & & $\begin{array}{l}=0,659 \\
=0,434 \\
=0,427 \\
=56,458 \\
=2,27 \\
=0,000 \\
=0,05\end{array}$ & & \\
\hline
\end{tabular}

Dari hasil perhitungan analisis regresi linier berganda yang telah dilakukan, menunjukkan pengaruh variabel independent terhadap variabel dependent adalah besar, hal tersebut dapat dilihat pada nilai koefisien determinasi $\left(\mathrm{R}^{2}\right)$ yaitu sebesar 0,434 yang sudah mendekati 1 . Dengan demikian berarti bahwa pengaruh keselamatan dan kesehatan kerja terhadap kepuasan kerja bagian pabrikasi pada PG Kebon Agung Malang dapat dijelaskan sekitar 43,4\% sedangkan sisanya sekitar 56,6\% dijelaskan oleh faktor-faktor lain yang tidak termasuk dalam penelitian ini. Berdasarkan tabel 4.8 yang menunjukkan hasil regresi antara keselamatan dan kesehatan kerja terhadap kepuasan kerja pada PG Kebon Agung Malang diperoleh nilai $F_{\text {hitung }} 56,458$ dan Sig F 0,000 . Hal ini berarti pada taraf kesalahan 5\%, secara simultan variabel keselamatan dan kesehatan kerja memiliki pengaruh yang signifikan terhadap kepuasan kerja. Dengan demikian Ha diterima, artinya ada pengaruh yang positif dan signifikan antara keselamatan dan kesehatan kerja terhadap kepuasan kerja. Nilai koefisien regresi $(R)$ sebesar 0,659. Nilai koefisien determinasi (R Square) sebesar 0,434 dapat diartikan bahwa variabel keselamatan dan kesehatan kerja secara bersama-sama mempengaruhi kepuasan kerja PG Kebon Agung Malang. 


\section{Pengaruh Keselamatan Kerja Terhadap Kepuasan Kerja}

Keselamatan kerja berpengaruh signifikan terhadap kepuasan kerja. Kepuasan kerja karyawan akan optimal apabila karyawan selalu terjamin keselamatan kerjanya, karena para karyawan yang bekerja mengharapkan kepuasan dari tempat karyawan bekerja. Kepuasan kerja pada dasarnya merupakan hal yang bersifat individual sebab setiap karyawan akan mempunyai tingkat kepuasan yang berbeda-beda sesuai dengan nilai-nilai yang berlaku dalam diri setiap karyawan. Berdasarkan hal tersebut, perusahaan PG Kebon Agung telah menyediakan fasilitas perlindungan fisik dan fasilitas perlindungan mesin kerja serta sarana mesin dan peralatan yang menunjang untuk digunakan karyawan pada saat bekerja maka akan tercipta perasaan puas pada diri para karyawan. Semakin tinggi jenis/ resiko dalam pekerjaan maka harapan karyawan untuk mendapat keselamatan kerja akan semakin tinggi juga, dan semakin tinggi pula tingkat kepuasan yang dirasakan. Perusahaan telah mengupayakan jaminan keselamatan dan menciptakan kondisi kerja yang aman dan bebas dari resiko kecelakaan, karena segala resikonya dapat menimbulkan kerugian moril maupun materil maka secara tidak langsung menghambat kelancaran proses produksi perusahaan. Dengan para karyawan lebih mengutamakan faktor keselamatan kerja tersebut diharapkan akan dapat meningkatkan kepuasan kerja karyawan karena karyawan akan lebih leluasa dalam proses bekerja sehingga tujuan yang ditetapkan perusahaan dapat tercapai. Hasil penelitian didukung penelitin terdahulu oleh Indra (2013) yang membuktikan keselamatan kerja berpengaruh signifikan terhadap kepuasan kerja karyawan, serta hasil tersebut sesuai dengan pendapat dari Mangkunegara (2000) tentang keselamatan kerja adalah menunjukkan kondisi yang aman atau selamat dari penderitaan, kerusakan atau kerugian di tempat kerja. Berdasarkan pendapat tersebut menyatakan bahwa kondisi yang ada di PG Kebon Agung Malang adalah aman dan selamat.

\section{Pengaruh Kesehatan Kerja Terhadap Kepuasan Kerja}

Kesehatan kerja berpengaruh signifikan terhadap kepuasan kerja. Hal ini dapat ditunjukkan dengan diberikannya fasilitas kesehatan kerja berupa adanya pelayanan kesehatan secara berkala dan klinik berobat untuk karyawan yang memadai akan dapat menimbulkan perasaan aman dalam bekerja. Apabila karyawan dapat bekerja dengan kondisi kesehatan jasmani yang terjaga, maka akan dapat menimbulkan dorongan untuk mencapai tingkat produktivitas yang lebih tinggi untuk perusahaan. Dengan demikian dapat diperoleh bahwa pemberian fasilitas kesehatan yang memadai dapat menciptakan kepuasan kerja pada karyawan. Hasil penelitian ini juga didukung dari jawaban responden bahwa kesehatan kerja yang diterapkan oleh perusahaan sudah sangat baik seperti terjaganya keadaan kebersihan lingkungan kerja, kondisi penerangan dan sirkulasi udara yang sangat mendukung di lokasi kerja, tersedianya fasilitas jaminan kesehatan BPJS untuk seluruh karyawan, keadaan sarana kamar mandi yang layak, dan pelayanan kesehatan kerja pada poliklinik yang sudah memadai. Hasil penelitian ini didukung penelitian terdahulu oleh Indra (2013) yang membuktikan kesehatan kerja berpengaruh signifikan terhadap kepuasan kerja karyawan, serta didukung oleh pendapat dari Mathis dan Jackson (2002), kesehatan kerja adalah kondisi yang merujuk pada kondisi fisik, mental dan stabilitas emosi secara umum. Berdasarkan pendapat tersebut menyatakan bahwa para karyawan PG Kebon Agung Malang merasa puas terhadap kesehatan kerjannya.

\section{Pengaruh Keselamatan dan Kesehatan Kerja Terhadap Kepuasan Kerja}

Hasil analisis dapat diketahui bahwa terdapat pengaruh signifikan antara keselamatan dan kesehatan kerja terhadap kepuasan kerja, hal ini sesuai dengan jawaban responden yang menyatakan bahwa fasilitas kerja yang ada sudah memadai yang terkait dengan keselamatan dan kesehatan kerja, agar karyawan dalam bekerja dapat menciptakan kepuasan kerja pada Pabrik Gula Kebon Agung, seperti lingkungan kerja yang aman dan nyaman, peralatan perlindungan kerja yang layak pakai, kondisi suhu dan penerangan yang mendukung serta jaminan kesehatan yang diberikan, sehingga karyawan di dalam bekerja merasa puas dan nyaman. Adanya keyakinan bahwa karyawan yang puas akan lebih produktif dari pada karyawan yang tidak puas, merupakan ajaran dasar diantara manajer selama bertahun tahun. Hasil analisis didukung oleh teori yang dikemukakan Robbins (2001), 
yaitu bahwa beberapa faktor yang dapat meningkatkan kepuasan kerja karyawan antara lain keselamatan dan kesehatan kerja. Hasil penelitian ini didukung dari penelitian terdahulu oleh Indra (2013) yang membuktikan keselamatan dan kesehatan kerja berpengaruh signifikan terhadap kepuasan kerja karyawan. Berdasarkan pendapat tersebut menyatakan bahwa para karyawan PG Kebon Agung Malang merasa keselamatan dan kesehatan kerja mempunyai pengaruh yang kuat terhadap kepuasan kerja.

\section{KESIMPULAN DAN SARAN Kesimpulan}

Berdasarkan hasil analisis dan pembahasan yang telah dilakukan pada bab sebelumnya, maka dapat ditarik kesimpulan sebagai berikut :

1. Variabel keselamatan kerja mempunyai perpengaruh yang signifikan terhadap variabel kepuasan kerja.

2. Variabel kesehatan kerja mempunyai perpengaruh yang signifikan terhadap kepuasan kerja.

3. Variabel keselamatan dan kesehatan kerja mempunyai perpengaruh yang signifikan terhadap kepuasan kerja.

\section{Saran}

1. Para karyawan hendaknya mengikuti SOP dan manajer memberikan kebijakan program keselamatan dan kesehatan kerja (K3) dan harus menerapkan seperti memakai perlatan keamanan yaitu helm kerja, sepatu anti strum dan selalu menggunakan masker.

2. Dilihat dari hasil kesimpulan bahwa secara keseluruhan kesehatan kerja merupakan faktor yang dominan mempengaruhi kepuasan kerja, oleh karena itu faktor kesehatan kerja sebaiknya lebih ditingkatkan dan seluruh para karyawan mendapat jaminan kesehatan sehingga para karyawan dalam bekerja lebih puas.

3. Dari hasil kesimpulan keselamatan dan kesehatan kerja diharapkan menjadi fokus tata kelola PG Kebon Agung Malang untuk terciptanya kepuasan kerja pada para karyawan.

\section{DAFTAR PUSTAKA}

Angkasa, D.S, 2014 Pengaruh Keselamatan Dan Kesehatan Kerja Terhadap Kepuasan
Kerja ( Studi Pada Karyawan PT. PLN (Persero) Area Kediri), Skripsi, Fakultas Ilmu Administrasi, Universitas Brawijaya: Malang

Arikunto, S, 2002 Prosedur Suatu Penelitian: Pendekatan Praktek, Edisi Revisi Kelima, Jakarta : Penerbit Rineka Cipta

Dessler, Gary, 1997 Sumber Daya Manusia, Edisi Bahasa Indonesia, Jilid 2, Penerbit PT. Prenhallindo: Jakarta

Handoko, T. H, 2001 Manajemen Personalia Dan Sumber Daya Manusia, Edisi 2, Yogyakarta: BPFE

Hariandja, MTE, 2002, Manajemen Sumber Daya Manusia, Grasindo, Jakarta.

Hasibuan, H Malayu S.P, 2007 Manajemen Sumber Daya Manusia, Edisi Revisi Kedua, Yogyakarta : BPFE

Ishak, A dan Tanjung H, 2004 Pengembangan SumberDaya Manusia, Jakarta: Universitas Trisakti

Mangkunegara, Anwar Prabu, 2000 Manajemen Sumber Daya Manusia Perusahaan,Cetakan Kedua. PT. Remaja Rosdakarya Offset. Bandung

Martoyo, Susilo, 1998 Manajemen Sumber Daya Manusia, Yogyakarta: BPFE.

Mathis, L.R. dan John H J, 2002 Manajemen Sumber Daya Manusia Edisi Pertama, Jakarta: Salemba Empat

Mathis dan Jackson, 2002 Manajemen Sumber Daya Manusia, Edisi Pertama, Salemba Empat

Mondy, Wayne, 2008 Manajemen Sumber Daya Manusia, Jilid Kedua, Edisi Kesepuluh, Jakarta: PT. Gelora Aksara Pratama

Munandar, 2008 Psikologi Industri dan Organisasi, Jakarta : UI Press

Panggabean, Mutiara S. 2004 Manajemen Sumber Daya Manusia, Jakarta : Ghalia Indonesia

PP No. 50 tahun 2012 tentang Penerapan Sistem Manajemen K3, www.asimaya.com

Priyatno, Duwi, 2013 Cara Kilat Belajar Analisis Data dengan SPSS 20, Edisi Kesatu, Yogyakarta : ANDI

Rivai, Veithzal. 2004 Manajemen Sumber Daya Manusia Untuk Perusahaan. Jakarta: Penerbit Raja Grafindo Persada.

Robbins, Stephen. 2003 Perilaku Organisasi, Jilid Kedua, Cetakan Pertama, Prentice Hall Inc. 
Santoso, W. et.al, 2008 Integrasi ekonomi ASEAN dan prospek perekonomian nasional. Outlook Ekonomi Indonesia 2008-2012, Jakarta: Biro Riset Ekonomi Direktorat Riset Ekonomi dan Kebijakan Moneter.

Siagian, P. Sondang, 2002 Manajemen Sumber Daya Manusia, Jakarta: Bumi Aksara

Singarimbun, M dan Sofian E, 2006 Metode Penelitian Survei, Cetakan Kedelapanbelas, Jakarta: LP3ES

Sugiyono, 2010 Metode Penelitian Kuantitatif Kualitatif dan $R \& D$, Bandung: $\mathrm{CV}$. Alfabeta
Su'maur, P. K, 2008 Higiene Perusahaan dan Kesehatan Kerja, Cetakan Keempat, CV. Haji Mas Agung. Jakarta

Tarwaka, 2008 Keselamatan dan Kesehatan Kerja. Manajemen dan implementasi K3 di tempat kerja, Surakarta: Harapan Press

Undang-Undang no 1 Tahun 1970 tentang Keselamatan dan Kesehatan Kerja www.asiamaya.com

Undang-Undang no 23 tahun 1992 tentang Kesehatan www.asiamaya.com

UU No. 13 Tahun 2003 tentang Ketenagakerjaan http://hukum.unsrat.ac.id/uu/uu_13_03.ht $\mathrm{m}$ 